\title{
WHY AREN'T WE BUILDING MORE SUSTAINABLE RESIDENTIAL NEIGHBOURHOODS IN THE UK?
}

\author{
T. TOWNSHEND \\ School of Architecture, Planning and Landscape, University of Newcastle, UK.
}

\begin{abstract}
If official rhetoric is to be believed, the UK has been quick to respond to growing global demands for greater sustainability in the way we create the built environment. At the national level there has been a plethora of planning and related guidance stressing the importance of sustainable development, and the need for more sustainable housing has been a key tenet of these texts. The Building Research Establishment has had guidelines and a rating system for more sustainable 'eco-home' developments since the 1990s. The majority of housing development in the UK, however, outwardly and in plan form at least, seems little different to that built 25 years ago. So why should this be so? Why, when national government policy seems so driven by the sustainability agenda and there are easily adopted national standards, should so little credence appear to be afforded them? This article begins to explore these tensions from the supply side of the equation and in particular in relation to the North East of England. It outlines the development of planning policy in the context of a growing sustainability agenda, the debates surrounding sustainable neighbourhoods and the pressure for new homes in the UK. The article then reviews an empirical research project which explores issues surrounding sustainable neighbourhood development with two types of housing provider. A group of volume house builders, used to providing the type of standardised products in developments that have faced much criticism in recent years and also bespoke providers, who are explicitly striving for more sustainable goals in their work, give their views. The research study covered a wide range of themes covering planning, construction and detailed design; this article focuses on the more 'macro' issues.
\end{abstract}

Keywords: housing, neighbourhoods, standards.

\section{INTRODUCTION}

Since the World Commission on Environment and Development published Our Common Future (The Brundtland Report) in 1987 [1], the concept of sustainable development has been high on the international agenda. At European level, the Commission of the European Communities (CEC) has called for higher density, compact cities, and mixed-use land policies [2, 3]. At national level, the UK was quick to respond to this impetus with its cross-departmental national strategy in 1994 [4] and sustainable housing became a key focus of UK government planning policies [5]. UK policy at this time was also influenced by US New Urbanism, bringing together ideas of traditional mixeduse, pedestrian orientated neighbourhoods, explicitly informed by mainland European cities $[6,7]$ with transit orientated development, (TOD); neighbourhoods built around transport connections of a sufficient size and density to support public transport $[8,9]$.

In 1999, a new national strategy for the UK was published aiming for a holistic approach to sustainable development and introducing the idea of sustainable development indicators which would be monitored and reviewed annually [10]. Seventy of these related to housing and the development of sustainable communities [11]. The year 1999 also saw the publication of the influential report Towards an Urban Renaissance [12] which clearly articulated the aspiration for more of the UK public to live in higher density, more urban and more sustainable communities. In response to this, the government produced an urban white paper and a raft of guidance, including setting a target for $60 \%$ of new housing to be built on urban land [13] and Planning Policy Guidance 3 [14] and its companion guide, Better Places to Live [15]. 
UK government policy for developing sustainable communities was further developed in 2003 with more government guidance $[16,17]$ and Planning Policy Statement 1 (PPS1), reiterating that sustainable principles must underpin the planning system and that the government was committed to producing 'vibrant and sustainable communities' [18]. The UK government launched its latest national campaign in 2005 [19] and most recently sustainable development has explicitly linked in to wider processes of community engagement and local empowerment [20,21]. All these government strategies are supported by a plethora of government-sponsored guidance, for planners and developers, citing good practice in the UK and elsewhere [22-24].

Given the apparent government impetus for sustainable communities it would be expected that new neighbourhoods based on sustainable planning principles, would have become relatively common places over the past decade; but this is not the case. While there are some well-known national exemplars, such as the Greenwich Millennium Village [25] and BedZED [26] much new volume housing in the UK fails to meet even basic sustainability criteria. Recent Commission for Architecture and the Built Environment (CABE) surveys of housing in both South East and North of England made woeful reading $[27,28]$. Although these audits concentrated on physical design quality, as opposed specifically to sustainability, many issues are clearly overlapping. A common criticism, for example, was that schemes were dominated by highway infrastructure and parking courts, vividly demonstrating the emphasis on private car transport, an absence of good design and little in terms of the sustainable principles promoted by the government.

\section{SUSTAINABLE NEIGHBOURHOODS, CONCEPTS AND KEY DEBATES}

Arguments surrounding the efficacy of developing the type of higher density, mixed use, culturally diverse neighbourhoods promoted in UK government policy are well rehearsed elsewhere [29-34], but in brief, the key arguments in favour of such neighbourhoods are that with higher density compact housing will consume less land; proximity to workplaces, shops and services will reduce the need for motorised journeys, especially when supported by a robust public transport system; this in turn will affect a modal shift away from private cars to public transport, which operates most efficiently in dense urban environments; and simultaneously all this will optimise the use of existing services and consume less energy and create less pollution. Thomas further suggests that despite concerns that such neighbourhoods do not provide the optimum building condition for 'green' buildings $[35,36]$ that increased densities and mixed uses have advantages that outweigh disadvantages, for example in thermal gain [37].

However, there are also clear arguments against such approaches to creating sustainable neighbourhoods. These are complex, but surround a number of key issues, e.g. the desirability of lifestyles offered by such neighbourhoods, the environmental degradation caused through loss of green space and increasing congestion, and the neglect of rural economies [38-41]. Recent research based on Oslo has added to the debate on the energy efficiency of dense urban neighbourhoods by questioning assumptions on household consumption and transport. The work suggests, for example, that while such developments generate less everyday travel, they distinctly increase leisure travel and that energy consumption patterns of single family dwellings, as opposed to multiple-occupation apartments, are less noticeable than might be supposed [42].

In the US, New Urbanist neighbourhood developments have certainly been criticised for not addressing ordinary homeowner's aspirations [43]. In the UK too there has been much criticism that the acceptability of higher density, more urban neighbourhoods, has been neglected and what research has been carried out seems to emphasise the enduring appeal of low density suburbia, for most groups in UK society [44-47]. There are, however, studies which suggest that the realities of standardised 
suburban developments in the UK do not necessarily match people's aspirations either [48] and that information gleaned from opinion surveys is 'complex and messages sometimes ambiguous' ([24], p. 2).

There are claims, particularly from the UK housing development industry, that the emphasis in government policy on locating the majority of new neighbourhoods on reused brownfield land is flawed in the UK, since it ignores the question of whether this land is where people want to live [49]. Recent research has shown that many brownfield developments produce highly desirable housing [50], but it is clear that tensions exist between developer opinions based on the perceived marketability of housing on certain development sites and the aspirations of public bodies. Issues around raising densities are another source of tension between official UK policy and developers. The National House Building Council has been quoted as claiming that there is general antagonism among the general public to higher density housing solutions [51] and academic research has also suggested that many people are reluctant to entertain notions of higher densities [52]. Recent residential post-occupancy research has suggested that people are willing to live at high density in a variety of forms in popular locations; however, this needs to be combined with factors such as generous internal space, insulation against noise transference between and within properties and an adequate sense of privacy [53].

\section{THE COMPLEXITY OF THE UK HOUSING POSITION; PRESSURE FOR NEW HOMES}

The development of UK policy is also set against a highly complex housing market. In essence, there is considerable evidence of a UK housing shortage, but there are also a number of mismatches between the location of supply and demand and between what is available and what people appear to aspire to [54]. In certain areas, mainly urban, former industrial areas in the North and Midlands there are considerable tracts of housing which lie largely vacant; these have been termed 'low demand' areas. In other parts of the country, particularly the economically buoyant South East, there are widespread housing shortages, particularly for affordable homes $[13,19]$. The net result of this situation is widely varying property markets in different parts of the UK. This is illustrated in Table 1, which shows average property prices for the key types of property available in the UK during the first quarter of 2005. It shows the property price differential between areas like the North East lag and the South East. More importantly, however, it also demonstrates that the market in the North East is dominated by terraced properties; these tend to be older mainly 19th- and early 20th-century properties the future of which has become a focus of much debate.

Former industrial urban areas of the UK have steadily lost population over the last four decades. Newcastle, for example lost $16 \%$ of its population from 1971 to 1991 . Some of this loss was due to economic migration to more prosperous regions as traditional industries closed (although there also

Table 1: Average house prices and percentage of sales January-March 2005.*

\begin{tabular}{|c|c|c|c|c|c|c|c|c|}
\hline & \multicolumn{2}{|c|}{ Detached } & \multicolumn{2}{|c|}{ Semi-detached } & \multicolumn{2}{|c|}{ Terraced } & \multicolumn{2}{|c|}{ Flat/maisonette } \\
\hline & $£$ & $\%$ & $£$ & $\%$ & $£$ & $\%$ & $£$ & $\%$ \\
\hline North East & 223,163 & 15.8 & 124,231 & 27.0 & 86,578 & 42.3 & 98,328 & 14.7 \\
\hline South East & 365,495 & 22.8 & 210,259 & 26.2 & 176,070 & 28.3 & 147,169 & 22.6 \\
\hline England & 275,693 & 19.5 & 160,234 & 26.3 & 140,591 & 34.0 & 152,508 & 20.0 \\
\hline
\end{tabular}

*Figures extracted from HM Land Registry database. 
been some short-range migration from urban inner city areas to more desirable suburban locations) $[55,56]$. The results of this migration, however, have been very uneven across city neighbourhoods in the region. As Table 1 suggests, the overall demand for terraced housing remains reasonably strong, but some pockets of this housing, both speculatively built 19th- and later 20th-century public stock have been badly affected, with some areas virtually abandoned. Much emphasis has been placed in public policy on the idea that such homes in low demand areas no longer meet potential resident's aspirations and that, therefore, they need to be demolished and replaced by new housing [57], and while this approach is debated [58], it is likely that in the North East, for example, several thousands of homes will go in the near future, many of which are currently occupied. Moreover, other trends boosting the demand for new dwellings are at work. People are living and wanting to live independently longer, single person households are increasing, numbers of families separating are also increasing and greater wealth is increasing the demand for second homes in popular locations. All these trends are set to continue [16].

Thus, while thousands of homes lie empty and deteriorating, in the North East, pressure remains for new homes in fashionable suburban and city centre locations. This demand will largely be met by the UK's private housing sector, as shown in Table 2 . At around 6,600, houses sold by private developers in 2004/05 represents around 8.7\% of the total houses sold in the North East during this period, illustrating that while significant the new build market in this region is still limited. It is, however, also a market, as in all UK regional markets, dominated by a relatively small number of companies.

In the UK, house-building firms are generally combined landowning companies. They buy and hold sites, until the market is right for development, build the houses on it and then sell them. This is in sharp contrast to many countries where relatively small house-building firms tend to buy serviced sites from land developers [59]. This combination of development and building affords UK developer-builders (often termed 'volume' builders) a high degree of power over local housing markets in Britain, where developable land is restricted and large firms dominate. Unfortunately, the result is that much new volume house building is of standardised, low risk, unimaginative developments that have attracted vociferous criticism from a range of official sources and amenity bodies over the past two decades $[27,28,60,61]$ and that have largely ignored sustainability debates [62].

A key area of debate around increased sustainability within the new build sector is naturally the cost implications that this entails. Table 3 shows that in the types of houses that dominate the lower end of the UK housing market, i.e. semi-detached and terraced properties, newly built homes can already appear relatively expensive. Whether people are prepared to pay even more, and if so how much, for houses which are more sustainable is a point for debate. Anecdotal evidence offered by volume builders in the research project reviewed in the next section of this article suggests not, but in fact in the UK there is limited evidence either way. BedZED the exemplar carbon neutral project in Sutton,

Table 2: New house completions in the North East.*

\begin{tabular}{|c|c|c|c|c|c|c|c|}
\hline & \multicolumn{2}{|c|}{ Private enterprise } & \multicolumn{2}{|c|}{ Registered social landlord } & \multicolumn{2}{|c|}{ Local authority } & \multirow[b]{2}{*}{ Total } \\
\hline & No. & $\%$ & No. & $\%$ & No. & $\%$ & \\
\hline 2003/04 & 5,469 & 94 & 333 & 5.7 & 18 & 0.3 & 5,820 \\
\hline $2004 / 05$ & 6,659 & 93 & 514 & 7 & - & 0 & 7,169 \\
\hline
\end{tabular}

*Figures extracted form Housebuilding Statistics, ODPM. 
Table 3: UK house prices by age of property January-March 2005.*

\begin{tabular}{lcccccc}
\hline & Pre-1919 & $1919-1946$ & $1946-1960$ & $\begin{array}{c}1960 \\
+ \text { not new }\end{array}$ & New & Average \\
\hline Terraced & 138,959 & 141,277 & 118,421 & 136,039 & 182,299 & 140,591 \\
Semi-detached & 234,866 & 169,614 & 138,293 & 142,063 & 159,153 & 160,234 \\
\hline
\end{tabular}

*Figures from Halifax Bank of Scotland.

South East England sold well with its properties approximately 10\% above prices of similarly sized dwellings in the area. Whether this success could be repeated in a weaker market, such as the North East remains to be tested. One of the key problems is that various sustainability measures cost vastly different amounts to install into new housing, therefore having vastly different on-cost implications to the purchaser; we will return to this issue in Section 4.1.

\section{THE NEWCASTLE RESEARCH PROJECT}

The empirical research covered in this part of the article is part of an ongoing research programme looking at issues of sustainable neighbourhood development in relation to the Northeast of England. In 2003, the author was retained by Newcastle City Council as consultant for a series of citizens' workshops exploring housing perceptions and choice. This study resulted in two key strands of findings. The first was that the current redevelopment of inner city areas in the UK may not be addressing ordinary peoples' housing needs and aspirations; the second was that generally people showed far more interest in sustainable housing developments and solutions than had been expected based on previous research [58].

Encouraged by the positive reactions to sustainable housing development, the city council instigated a desk-based scoping exercise to review existing sustainability standards and advisory documentation, both in print and web-based within the UK. This was followed by an analysis of these to highlight emergent themes, trends and overlaps, inconsistencies and contradictions and inadequacies and omissions. The results of this stage of the work produced a framework of research themes for further investigation with housing providers. These were:

- The use or otherwise of Building Research Establishment (BRE) eco-homes standards.

- Provision of mixed-use neighbourhoods and specifically the willingness of developers to provide shops and services within housing developments.

- Transportation to and from and circulation within housing developments; the amelioration of private cars and the maximum exploitation of public transport. Construction of 'Home Zones' adopting ideas from Dutch woonerf planning [63].

- Orientation and the use of passive solar gain and the active use of onsite renewable energy sources.

- Water conservation and sustainable drainage.

- Onsite waste recycling.

- Site ecology.

- Safety in particular attitudes to 'Secured by Design' standards; a UK police force initiative [64].

The study also explored in more detail aspects such as building materials and construction, including local sourcing to cut down on unnecessary transportation; the durability, reparability and 
recyclability of the materials used in construction; exploitation of prefabrication to cut down on the waste from traditional construction methods and to ensure build quality; energy use in construction and running buildings; building longevity and maintenance; and internal flexibility of buildings to meet changing needs and aspirations of future owners without major works. Detailed synthesis and analysis of these aspects of sustainable housing will be published elsewhere. This article will, however, consider the impact of BRE eco-homes standards which relate to some of these issues [65]. Although there are a plethora of publications relating to sustainable housing standards in the UK, BRE standards are important, first, because they are long established, adapted from earlier environmental standards for offices [66] and they are comprehensive, based on widespread consultation with the UK's environmental and construction sectors to establish what they perceived as the most important aspects of sustainable housing and their relative importance to one another [67]. They are, therefore, the nearest the UK has to nationally accepted guidelines for sustainable housing development; although there is no legal compulsion to adopt them, and while developers such as registered social landlords (RSLs) have widely adopted them, what research there is suggests that take-up by private builders is much slower [68].

The early stages of the research involved identifying two types of building firms to be approached for study. First, those volume house builders dominating the new build sector of the North East regional housing market and, in contrast, pioneer bespoke housing providers active within the field of sustainable housing development. This latter group was not restricted to the North East region since this would have been overly limiting and scoping research had demonstrated that sustainable housing development was more advanced elsewhere in the UK. In late 2004, a list of 20 companies were identified and approached for interview. These were the 10 most productive volume house builders in the region based on planning permission submission; the four largest social housing providers in the region and a further six firms both local and national who had established a reputation for sustainable construction; these latter 10 companies were grouped together for the purpose of the study and referred to as 'bespoke and pioneer' housing providers.

In total 12 firms agreed to take part in the study. These included five volume house builders, representing the bespoke and pioneer housing providers; two RSLs; a company specialising in student and key worker accommodation; a firm specialising in medium-high market sustainable family housing; a small design and build company specialising in timber frame construction; a firm of architects who have been working with various clients to design bespoke housing in the Northeast; and a pioneering residential/commercial developer specialising in brownfield regeneration sites. Of the eight companies who did not take part in the study, two specifically stated they were unable to take part, one due to staff shortages and one due to a recent change over in staff; the rest were noted as simply non-respondent, i.e. they failed to respond to multiple (a minimum of three) approaches. It was difficult to draw any firm conclusions from the non-respondent firms, or whether this had any particular bearing on the outcome of the research. Looking at the volume house builders, however, the companies were well spread in terms of productivity including three of the top ranked five companies. In relation to the bespoke and pioneer group, it was not intended that this group would necessarily reflect the full spectrum of companies operating in this field, but that they would provide examples of alternative perspectives to the dominant UK market perspective.

The interviews were carried out at the end of 2004 and first quarter of 2005. They were semistructured following the themes identified above, but adapted within interviews to address provider's particular circumstances and to allow the research to respond to issues raised by the interviewees themselves. The interviews were fully transcribed and then perspectives expressed on the various themes extracted. This generated a very large amount of data. This part of the article, therefore, gives an overview of key responses, though necessarily some detailed issues had to be omitted. Finally, several of the companies were concerned with confidentiality and the sensitivity of the 
information they were supplying and it was agreed that all information would be anonymised; therefore, all quotes within this text follow this agreement.

\subsection{BRE and eco-homes standards}

Although this article is focused on macro issues of planning and design, it is essential to review attitudes towards BRE eco-homes standards because these standards span the macro issues of public transport, local amenities and so on, through to micro construction issues. Also, while there is no compulsion to adopt them, they are the nearest the UK has to nationally accepted standards for sustainable development. Having said this, among the interviewees, take-up of BREEAM eco-homes standards could be described at best as partial. Although all but one of the bespoke companies had used BRE standards at some stage, only one volume house builder had and many of the others in this group professed little, or no, knowledge of the scope or content of the standards.

Eco-homes rating operate on a system, whereby sustainability measures incorporated within a scheme are allocated points and this is translated into a rating of pass, good, very good, or excellent. One of the key concerns with those using eco-homes rating was the equity of this system. For example, simple and inexpensive items like providing water butts for rainwater awarded 1 'eco' point, or bicycle storage 2, but providing relatively complex issue, such as a carbon neutral home is only worth 10 . Interviewees thus felt that scores could be easily manipulated to make developments look more ecofriendly without necessarily raising standards that much, one commented 'it seems to be one of those things where if you know the rules from the outset you can then use the assessment criteria to give you an excellent output, as opposed to making an assessment after the building has been designed' (emphasis added). Another complaint was that, whilst it was relatively easy to reach 'very good' standard on almost any development raising this to excellent was 'in large measure a function of the location rather than product'; so, no matter how good the actual dwellings developments would not get an excellent rating without first-rate public transportation links which were often out with the developers control.

Another concern that was common was the self-reporting nature of BRE eco-homes ratings and it was suggested that this was open to abuse. Participants were keen for a secondary proof of evidence to be required to show that standards had indeed been met. Moreover no post-occupancy surveys were carried out to make sure buildings and materials were performing as they should be, this was another major cause for concern, as some of the technology used in schemes was relatively new and untested. Those who had used eco-homes ratings were also not necessarily that impressed with the level they represented, or the benefits of going though the rating process. One bespoke developer stated that they had only put one scheme through eco-homes standards, primarily because they viewed the ecohomes excellent standards as inferior to their own. Another disadvantage expressed was that when a developer had gone though eco-homes rating it meant nothing to the purchasers of their properties, 'we've not found that eco-homes rating system has been marketed to purchasers in a way that makes them come to us'.

Some developers clearly felt that their adoption carried an economic disadvantage, when one of the bespoke providers were asked what the barriers were to building eco-homes to 'very good' or 'excellent' standards, they responded 'competing for land against standard house builders', clearly articulating this. At the time of the research, there were no clear guidelines as to cost of improving non-compliant housing to eco-homes good, or excellent, standards. When the developers were asked how much they estimated it would cost to reach eco-homes very good, or excellent within their developments figures ranged vastly, with most volume builders estimating 20-25\%. In fact, subsequent research by BRE has shown that improving a basic house type in a typical location to eco-homes 
'very good' should cost around 1.7\% extra and to 'excellent' 7\% [69]. In Walker, Newcastle the cost of a development of excellent rated homes was estimated to be $7.5 \%$ over and above standard development costs which lends to support BRE's figures.

Apart from cost, the thrust of the volume house builders' perceptions of eco-homes standards related to the issue of house buyers perceptions. Generally they suggested they only incorporated what people asked for and only if people became more educated in issues relating to sustainability did they see an inducement to build more sustainable properties. One volume company had specifically produced ecohomes and thought that sustainable development was a selling point to a limited degree, although none of the others concurred with this view. This is interesting, since much of BRE documentation has been couched in terms of the benefit of achieving certification is that it allows developers to differentiate their developments from other less-sustainable ones and therefore improve their marketability [67].

\subsection{Building mixed-use developments with neighbourhood shops and services}

The most comprehensive experience of creating mixed-used development, particularly providing shops and neighbourhood services within housing developments, came from the RSLs. One commented, however, that although they still provided community buildings within housing developments on some of their larger developments that they had not built new shops for around 30-40 years, the key issue they cited was the complexity of funding and legal arrangements involved. The most pressing challenge for most participants, however, was clearly in managing demand for shops and services. The second RSL, for example, commented that in principle they were in favour of providing shops and services, but in their experience there often simply wasn't the demand to justify them 'in terms of sustainability', clearly meaning their capability to survive in a business sense.

A critical issue expressed was that of timing and demand. If shops and services are not there at the beginning of a development, it was difficult to get people to use them, because they get into the habit of driving to nearby facilities. If they are incorporated too early in the stages of development, however, it was difficult to sustain them without subsidy; the opportunity for shops and services to provide for contractors during construction was seen as positive, but still not necessarily enough to ensure their viability. There seemed to be a need, therefore, for some form of public intervention and support in these early stages, if mixed use neighbourhoods are to be successful.

That developers generally receive a far smaller return from shop units, than additional residential units was also felt to be the general problem in encouraging mixed use development. Volume builders expressed the concern that in a highly competitive development market such issues were often make or break factors in profitability. One provider commented, however, that in urban projects arguments in favour of mixed uses were augmented by 'the idea of having animated ground floors which help in terms and security and well-being and bring life to those streets and generally reinforce the viability of our scheme'. Trying to ensure success for mixed uses, for example defining housing densities to support particular services and so on, was viewed as impossible.

In practical terms, providing residential units above shops was not seen by most developers as unduly problematic and some had had experience of this, although more often in refurbishment projects rather than new buildings. One developer did, however, comment that physical constraints were sometimes an issue, citing an example of building over a coach station where the open nature of the concourse rendered the site extremely expensive because the large widths that had to be spanned. In contrast, the same developer had built over small shop units and this had proved ideal, since services could be run through columns to upper floors which did not impact the ground floor users. Another provider talked of conflicts of interest in terms of noise generation, use of bin stores and so on, between residential and commercial users, but also added these things 'just needed to be sorted 
out'. Even the volume builders, who overall professed little experience of living over shop schemes, agreed that there was generally little complication in their development.

\subsection{Transportation and onsite circulation}

The bespoke providers were all extremely positive with regard to good public transport services, with one of the social housing providers commenting, 'we would always seek to ensure any development we do is close to a good transport node ... and in fact we would, if appropriate seek to encourage local bus companies to divert services through new development'. The student and key-worker housing provider also stated that access to travel facilities was a key driver in development location. However, none of the developers had specifically developed sustainable travel plans for their developments.

In relation to ameliorating vehicular traffic within developments, generally all developers felt that this was a positive intervention. With most volume builders, however, the concerns were as much aesthetic, considering that large areas given over to car parking could be detrimental to the final value of their schemes, as opposed to discouraging private car use. Moreover, only four developers were either actively developing schemes to 'Home Zone' principles or had already done so. They also agreed that designing in Home Zone principles did incur extra cost, but felt unable to quantify this in a straightforward cost comparison with other schemes. Two of the developers working on Home Zones were volume house builders. One specifically added that they felt Home Zones worked well on smaller schemes, but not on larger developments, because they became too complex. Two of the developers stated that they had had problems of implementation, because various elements within schemes conflicted with extant highway regulations; this had left them with mixed views on the desirability of developing further Home Zone schemes.

Other respondents talked more generally of the tensions of trying to ameliorate the impact of cars within developments and highway and car parking standards imposed by local authorities. One respondent, citing an apartment development adjacent to the city centre, angrily commented 'one car parking bay per household would have easily been sufficient, but they [the local authority] demand 1.3'. One of the social housing providers also suggested that in some of their schemes while many of their occupants did not own a car, local authorities had 'regularly sought to impose 2 parking spaces per dwelling'; in one scheme, they had provided tens of car parking spaces where only two tenants had a car, which the respondent found particularly frustrating; although there was also a feeling that standards were gradually being relaxed at least by some authorities. Overall, however, there was quite a degree of bitterness expressed among respondents that on the one hand they were being told to reduce car impact, but still were expected to meet stringent highway and parking standards, which in many cases seemed to run counter to this aim.

Nearly all the interviewees felt that car free developments were not feasible except in very central locations in the UK at this point in time. One bespoke provider commented, 'we'd aspire to car free developments, but no it's virtually impossible'; another stated, 'personally I don't think that would ever be particularly possible. Society is built so closely round the car that you have to accommodate it somewhere to a degree'. Generally, it was also felt that car free developments were only possible for certain types of housing, such as key-worker provision adjacent to sites of employment and the provider of student accommodation had provided car free developments where alternative transport was of a good enough quality.

The concept of car-pooling received a more mixed reaction; one bespoke respondent stated, 'that requires a level of co-operation and commitment which I feel uncomfortable about requiring'. Size of development was a key issue here; one bespoke developer who was very keen on the issue, but whose largest development was only 20 houses, stated that this was definitely too small for the 
schemes to be viable. They also went on to say that they felt such schemes would work much better where employment uses were part of the development and such services could be more closely interdependant with these. However, two other bespoke developers were actively pursuing the idea. One was exploring the possibility of setting up a car club, the running of which would be handed over to the local authority. The other company were at present in negotiation with a local government transport body over adoption issues for their scheme. Both these participants stated that the adoption of such schemes was far more complex than they had anticipated and felt that local authorities were generally unprepared for such schemes.

\subsection{Site orientation and onsite renewal energy}

There was quite a wide range of experience of passive solar gain among bespoke developers, although there was also a degree of scepticism as to its efficacy in the UK, as one commented 'in this country considering the hours of daylight the sun shines, you're going to need a back up system!', and another commented 'it's a pretty low priority I have to say'. Two bespoke developers were using the principle with complete success, however, as one had undergone a steep learning curve making mistakes, but stated that now 'using orientation to heat and wind to cool is very important to us'. Three of the five volume house builders acknowledged passive solar gain as an issue of interest. One used the principle for conservatories, although not their main houses; one linked it through to marketing and the premium people would pay for south and west-facing elevations; and one was actively pursuing this in larger developments, but not to the extent of producing highly glazed elevations. Of the other two developers, one commented that they definitely could not achieve passive solar gain with their current housing designs and, therefore, were unlikely to undertake such a scheme.

The application of passive solar gain was somewhat indicative of much of the attitude expressed towards sustainable development by participants. This was a certain cynicism in terms of how far one could push sustainable technology in new neighbourhoods in two ways. First, in the applicability of some technologies in the UK particularly anything to do with solar capture. The second was just how radical a change in housing design was generally acceptable to the market. These attitudes were somewhat expected from volume builders, with long-established standardised products, but there was a surprising level implicit in the bespoke responses too. This in turn suggested two important issues, first that lessons are not being learnt from countries where climatic conditions are comparable or even more adverse, but where sustainable housing projects are more developed, e.g. Scandinavia, Germany and Austria. Second, that inherent conservatism in housing design supposedly supported by consumer aspiration although not necessarily that robustly supported by research may be detrimental to achieving real gains in the arena of sustainable development in the short to medium term. Here, the house-building industry might learn from other industries such as automotive production where innovation is a key element of selling products. Both need addressing urgently with more research.

Onsite renewable energy sourcing was another topic about which cynicism was expressed. Several bespoke developers suggested that it might be possible to provide enough energy on site and some were pursuing this, although it was still very much at an experimental stage. Overall, however, most felt that it would be extremely difficult and relatively expensive. One provider said, 'We've looked at wind power ... to try out some little turbines, but the general feedback we get is it will never keep the energy going'. The volume builders also generally agreed that in principle such schemes were possible, but again voiced concerns over the acceptability to buyers and felt, for example, turbines would be deemed to be unsightly among most housing developments. Energy saving, rather than self-sufficient schemes were also on the drawing board. Opinion here was that geothermal and solar thermal had distinct possibilities; that photovoltaic panels were not currently economically viable 
(and some felt the technology for their production was suspect in sustainability terms) and that wind turbines were more of a gimmick than a serious proposition.

There was a mixed reaction among providers when asked if they could deliver a carbon neutral housing development. One firm was extremely positive and said they had already prepared a carbon neutral development option for a particular site, for which they felt there was a 'definite market' in the Northeast; however, they added 'whether the client is prepared to do that is another matter'. Another stated that although they could not deliver it at the moment, they were looking at carbon neutral in a forthcoming planned development, not over the entire site, but at least a proportion of it. When they were asked if they felt there was a market for this, they said that this was not the driving force behind this project, but that they were seeking to demonstrate the practical and technical aspects of such a development; they added 'it won't be commercially viable because the cost will be too high'. A sentiment echoed by another developer with a scheme on the drawing board, who admitted it was beset with problems and felt that budgetary issues would probably prevent the scheme from being entirely carbon neutral on completion.

\subsection{Recycling, water conservation, and ecology}

In terms of recycling, most providers were keen to promote and cooperate with local authority-run kerbside collection schemes. There were detailed discussions looking at elements, such as kitchen design, although generally overall site planning was less affected. One participant had been using a Scandinavian system of having a recycling centre rather than a bin store, with 20-30 apartments sharing an enclosure where people separated their waste into different containers; 'it actually saves us money because if the bin lorry only has to come to the entrance of the scheme so the roads can be smaller'. Generally, making schemes extremely easy to cooperate with was seen as crucial. Onsite composting was not widely developed, although interestingly one of the volume builders had developed a scheme and felt it was working successfully.

Experience with water recycling was mixed. Rainwater capture was the area which was most advanced. Where rainwater harvesting was employed one bespoke provider stated that even on relatively tight schemes it was possible to deal with surface water onsite, 'without too much difficulty', although onsite schemes to deal with grey water recycling were non-existent and all the participants from this study, both volume and bespoke providers, felt such schemes were prohibitively expensive. Practical experience of sustainable drainage systems (SUDS) was somewhat limited, although one of the social housing providers was developing a new scheme based on SUDS including ' ... balancing ponds, home drainage channels throughout the scheme and so on'. Two of the other providers were using SUDS without issues.

Elsewhere, however, companies had looked at SUDS and felt that potentially they were a good idea, but concerns were raised over the adoption and management of such schemes. One stated in a planned use of SUDS that the local Water Company would not manage the scheme saying that this was the responsibility of the local council; however, the developer claimed the local council had also been unwilling to adopt the scheme; in the end it had not gone ahead. Such issues were reminiscent of the debates around the adoption of car pooling schemes and this does suggest that some local authorities have yet to address some of the more complex issues surrounding sustainable neighbourhood development and need to do so if this type of development has any chance of success.

In terms of ecology developers were positive about using native species in landscaping schemes and none of them felt that such an approach should be an issue. Beyond this very general acceptance in principle, however, it was difficult to draw many firm conclusions about the developer's thoughts on ecological issues. For example, one developer claiming to use largely native plants went on to 
mention popular plants in their schemes which weren't in fact native, but were clearly chosen for their low maintenance and intruder deterrence, introducing sustainability questions of a rather different nature. One respondent summed it up as, 'the driver for us is about the environment which gives the appearance of sustainability I suppose'.

Two of the volume house builders stated that they had no interest in the ecology of their sites at all. Of the other three, two claimed they had set out ecological gardens, although one also added that they found resistance from local residents as the areas tended to look unsightly and overgrown. Setting aside an area purely for ecological purposes was something that most of the bespoke providers felt was an interesting idea, but was very much site-dependant, sometimes places were left to go to nature by default, however, 'it's one of those things you've done just accepting that for part of the site its best for its to go to wilderness'. Another issue was that it was felt communal areas were only successful in certain types of scheme, such as sheltered housing. There was a high level of consensus from all participants that shared space of whatever nature was not a good idea on general housing schemes.

\subsection{Safety}

In terms of ensuring perceptions of safety in neighbourhoods, 'Secured by Design' standards were widely known [64]. Not all respondents, however, were happy with them, or at least the way in which local police forces (through police architectural liaison officers) were interpreting them. Some of the bespoke developers were particularly critical; one talked of direct conflict with the police over a scheme stating, 'I think Secured by Design is flawed ... they [the police] were just saying stick some big roll of shutters up and we were saying no, we don't want to, we'll take the cost of having the windows broken on the basis that that stops and you end up having light and life coming onto the streets which is important ...'; another stated '... we're committed to the secure by design principles, but I don't think we're committed to how some police forces implement them ...'.

The volume house builders were more supportive of Secured by Design, liking the degree of certainty such standards offered, but they also raised issues of interpretation. The key area of conflict, however, was that Secured by Design still seemed to favour limited access and cul-de-sac designs, high perimeter walls and fences, and inward looking surveillance; whereas advice contained in Planning Policy Guidance Note 3 [14] and subsequent advice [15] had moved away from this type of planning towards permeability, although routes and addressing the surrounding area.

\subsection{Policy implications}

The interviewees were not specifically asked for their views on the policy implications for central and local government arising from the various issues they raised; however, a number of themes emerged pertinent to this topic. In relation to central government, the key concern was that most policy, such as the 'Creating Sustainable Communities' agenda being developed by the then Office of the Deputy Prime Minister, was little more than rhetoric and would have little real impact, 'the government have got to place a higher emphasis on it, they have to demonstrate a greater commitment' was a typical comment from a bespoke provider, generally frustrated at what they felt was inaction by the government. A very basic point was that they felt it was the central government's responsibility to lead on a 'hard-hitting' mass public awareness campaign on the need to build more sustainably and that this was not something that should be left to the house builders themselves. In terms of forcing the hand of developers to build more sustainably, improving building regulations were seen as the most effective measure that the central government controls. Tightening up planning controls was important, but not seen as an affective measure on their own by the interviewees. In fact, new building 
regulations on the conservation of fuel and power in new dwellings were at that time being prepared and many of the developers were not only aware of the implications of the new standards, but also were complying to them. Again, however, there was a clear frustration among bespoke providers that this type of legislation was not moving far, or fast enough.

Generally respondents also felt that while introducing tougher regulations was important, incentives (basically financial incentives) also had to be addressed, 'if everyone built to eco-excellence for example then the cost of construction would be increased but when companies were bidding for land people's calculations would be the same'. Direct financial incentives to the developer were a possible measure. English Partnership's (the national regeneration agency) example of selling land at a cheaper price, if being developed to a higher sustainability standard was cited as an exemplar of good practice by bespoke developers. It was also thought that financial incentives could be delivered to the consumer through, for example, tax incentives for compliant housing so that overall cost increases to the consumer were reduced in size.

There were also clear implications for local planning authorities in relation to several issues. Trying to pre-empt problems with highways standards and issues around Secured by Design principles by working across relevant departments and with agencies involved was one specific area for improvement. Developing a proactive approach to issues such as car pooling, the adoption of home zones and SUDS, so that clear policies are in place if developers wish to develop such measures is another. Moreover, local authorities can take a firm lead with land in their own ownership in terms of demanding developments meet high sustainability standards whether they be to BRE eco-homes standards, or alternatives they develop themselves. Local authorities might also take a lead in developing practical demonstration projects. One respondent paralleled the contemporary situation of sustainable development to the regeneration of city centres through residential development two decades ago. City centre residential development was started by small bespoke companies as a fringe activity. In most UK city centres today, however, such companies have been effectively squeezed out by major developers, 'I think ... it's about showing them they can make money out of this (sustainable development) ... and that's for local authorities to work with the little companies to deliver demonstration projects'.

\section{DISCUSSION AND CONCLUSIONS}

The UK government has produced a huge amount of rhetoric over the past two decades about the need to build more sustainably and there is now a plethora of government-sponsored guidance on good practice for planners and developers to follow in this respect. A few exemplar projects have been built which demonstrate that not only can we build in more sustainable ways, but such developments can meet the needs and aspirations of homeowners in the 21st century. And yet most new housing developments in the UK seem to largely ignore sustainable development principles. Standardised, unimaginative developments abound which in plan form and general appearance, have changed little in the last two and half decades.

Most new housing in the UK is produced by a small number of large firms, and these volume house builders have been portrayed negatively as being solely responsible for producing the poor quality housing that is commonplace in the UK. To an extent this criticism is justified and certainly the research showed little impetus among the volume interviewees in terms of pursuing more sustainable planning in their housing schemes. The volume builders' defence is largely framed around the argument that they simply supply what the market wants. Actually across the participants there was general agreement that thus far public demand for sustainable housing seemed limited, but whether this was fuelled by consumer apathy or a simple lack of demand was open to debate. One bespoke provider commented, 'the housing field is controlled by people who don't seem to exhibit any interest in 
sustainability whatsoever, who still sell $95 \%$ of the houses in this country, it is a depressing picture'. Another of the bespoke providers, an RSL suggested 'I don't think the people moving into our properties ... actually have an appreciation of the sustainability issues around them'. Recent research including consumer attitudes towards sustainable housing in the North East, however, has given a rather more hopeful perspective. Moreover, many industries such as the automotive industry thrive on innovation and persuading consumers that issues such as increased sustainability, safety and so on are things that they should be aspiring too and paying for. The lack of innovation in the housing industry seems hard to justify in comparison.

There was also, however, a widely held belief among participants that in terms of what can be done to induce building and delivering sustainable housing for the mass market, raising awareness through widespread and sensitively articulated education programmes among the house buying public were absolutely essential. In this respect, it was seen as the responsibility of central and local government, as well as the housebuilders themselves, 'I don't think it's something house builders can lead on, it's about awareness raising and customer demands to which house builders respond', was a typical comment. Although much of the research seemed singularly pessimistic in terms of any short-term and rapid increase in the number of sustainable homes being built in the UK, there were some positive signs. One of the volume builders, for example, commented that they felt they needed to do something to show people that they 'really do care' and to 'keep a good name' in the market. Another volume developer who at this stage was not at all interested in sustainable housing also stated that he thought this could change and that all the volume house builders would probably 'jump on board at the same time'.

Government guidance in the UK is clearly focussed on sustainable housing development, neighbourhoods and communities; but this advice has thus far only delivered a very limited amount on the ground. Moreover, there is little evidence that this situation is set to change in the short or medium term. If the sustainability agenda is really going to be delivered, then far-reaching steps must be taken. A major overhaul in legislation, a targeted and sustained education campaign, a review of financial incentives and the execution of financially attractive demonstration projects are all required. Whether there is any real appetite for such a radical shake up of the way new neighbourhoods are built, by the UK government, however, remains open to debate.

\section{REFERENCES}

[1] World Commission on Environment and Development, Our Common Future, Oxford University Press: Oxford, 1987.

[2] CEC (Commission of the European Communities), Green Paper on the Urban Environment, CEC: Brussels, 1990.

[3] CEC (Commission of the European Communities), Sustainable Cities Report, CEC: Brussels, 1990.

[4] HM Government, Sustainable Development - the UK Strategy; Cmnd 2426, HMSO: London, 1994.

[5] McGhie, C. \& Girling, R., Local Attraction. The Design of New Housing in the Countryside, Council for the Protection of Rural England: London, 1995.

[6] Duany, A. \& Plater-Zyberk, E., Towns and Town Making, Rizzoli: New York, 1991.

[7] Katz, P., The New Urbanism: Towards an Architecture of Community, McGraw-Hill: New York, 1994.

[8] Calthorpe, P., Pedestrian pockets: new strategies for suburban growth. The Pedestrian Pocket Book: A New Suburban Design Strategy, ed. D. Kelbaugh, Princeton University Press: Princeton, pp. 7-24, 1994. 
[9] Calthorpe, P., The Next American Metropolis, Community and the American Dream, Princeton Architectural Press: New York, 1993.

[10] HM Government, A Better Quality of Life - A Strategy for Sustainable Development for the UK, HMSO: London, 1999.

[11] Elkins, P., The Big Picture, Social Housing and Sustainability, The Housing Corporation: London, 2000.

[12] Urban Task Force, Towards and Urban Renaissance, E \& FN Spon: London, 1999.

[13] DETR, Our Towns and Cities: The Future - Delivering an Urban Renaissance, DETR: London, 2000.

[14] DETR, Planning Policy Guidance Note 3 Housing, DETR: London, 2000.

[15] DTLR \& CABE, Better Places to Live: By Design - A Companion Guide to PPG3, DTLR \& CABE: London, 2001.

[16] ODPM, Planning for Sustainable Development; Towards Better Practice, ODPM: London, 2003.

[17] ODPM, Sustainable Communities: Building for the Future, ODPM: London, 2003.

[18] ODPM, Planning Policy Statement 1: Delivering Sustainable Development, ODPM: London, p. 7, 2005.

[19] HM Government, Securing the Future, Delivering the UK Sustainable Housing Strategy, HMSO: London, 2005.

[20] ODPM, Sustainable Communities: Homes for All. A Five Year Plan from the Office of the Deputy Prime Minister, ODPM: London, 2005.

[21] ODPM, Sustainable Communities: People, Places and Prosperity. A Five Year Plan from the Office of the Deputy Prime Minister, ODPM: London, 2005.

[22] Llewelyn-Davies, The Urban Design Compendium, English Partnerships/The Housing Corporation: London, 2000.

[23] DETR/CABE, By Design. Urban Design in the Planning System; Towards Better Practice, DETR: London, 2000.

[24] CABE, What Home Buyers Want: Attitudes and Decision Making Among Consumers, CABE: London, 2005.

[25] Hansen, L., Greenwich Millennium Village: a revolution in volume housing? Eco Design, 7(3), pp. 10-13, 1999.

[26] Dunster, B., BedZED - Beddington Zero - fossil fuel development. Sustainable Urban Design, An Environmental Approach, ed. R. Thomas, Spon Press: London, pp. 167-183, 2003.

[27] CABE, Housing Audit: Assessing the Design Quality of New Homes, London, the South East and the East of England, CABE: London, 2005.

[28] CABE, Housing Audit: Assessing the Design Quality of New Homes in the North East, North West and Yorkshire and Humber, CABE: London, 2005.

[29] Newman, P. \& Kenworthy, J.R., Sustainable urban form: the big picture. Achieving Sustainable Urban Form, eds K. William, E. Burton \& M. Jenks, E \& FN Spon: London, pp. 109-120, 1989.

[30] Sherlock, H., Cities and Good for Us, Paladin: London, 1991.

[31] McClaren, D., Compact or Dispersed? Dilution is no solution, Built Environment, 18(4), pp. 268-284, 1992.

[32] Jenks, M., Burton, E. \& Williams, K. (eds), The Compact City a Sustainable Urban Form?, E \& FN Spon: London, 1996.

[33] Kunstler, J.H., Home from Nowhere: Remaking Our Everyday World for the Twenty-First Century, Simon \& Schuster: London, 1996. 
[34] Williams, K., Burton, E. \& Jenks, M. (eds), Achieving Sustainable Urban Form, Spon Press: London, 2000.

[35] Steemers, K., The paradox of the compact city, Architects Journal, 2 November, pp. 42-43, 2000.

[36] Barker, M., Solar ElectriCity Guide, Institut Cerda: Barcelona, 2001.

[37] Thomas, R., Building design. Sustainable Urban Design: an Environmental Approach, eds R. Thomas \& M. Fordham, Spon Press: London, pp. 46-62, 2004.

[38] Breheny, M.J., Sustainable Development and Urban Form, Pion: London, 1992.

[39] Breheny, M.J., Urban compaction: feasible and acceptable. Cities, 14(4), pp. 209-217, 1997.

[40] Breheny, M.J., Gurney, A. \& Strike, J., The compact city and the need to travel: the implementation of UK planning policy guidance. The Compact City: A Sustainable Urban Form?, eds M. Jenks, K. Williams \& E. Wilson, E \& FN Spon: London, pp. 13-35, 1996.

[41] Frey, H. Designing the City: Towards a More Sustainable Urban Form, Spon Press: London, 1999.

[42] Horland, E. \& Norland, I.T., Three challenges for the compact city as a sustainable urban from: households consumption of energy and transport in eight residential areas in the Greater Oslo Region. Urban Studies, 42(12), pp. 2145-2166, 2005.

[43] Morrow-Jones, E.G.I., \& Roe, B., Consumer preferences for neotraditional neighborhood characteristics. Housing Policy Debate, 15(1), pp. 171-202, 2004.

[44] Mulholland Research Associates Ltd, Towns or Leafier Environments? A Survey of Family Home Buying Choices - Summary of Main Findings, House Builders Federation: London, 1995.

[45] Forest, R., Kennet, T. \& Leather, P., Home Owners on New Estates in the 1990s, Policy Press: Bristol, 1997.

[46] Hooper, A., Dunmore, K. \& Hughes, M., Home Alone, Volumes 1 and 2, National House Building Council: Amersham, 1998.

[47] Senior, M.L., Webster, C.J. \& Blank, N.E., Residential preferences versus sustainable cities; quantitative and qualitative evince form a survey of relocating owner-occupiers. Town Planning Review, 75(3), pp. 337-357, 2004.

[48] Andrews, C.L., Reardon-Smith, W. \& Townshend, M., But Will We Want to Live There? Planning for People and Neighbourhoods in 2020, Women and Housing: Didcot, 2004.

[49] House Builders Federation, Places for People: Comments for the Proposed Urban White Paper, HBF: London, 2000.

[50] Tiesdell, S. \& Adams, T., Design matters: major house builders and the design challenge of brownfield development contexts. Journal of Urban Design, 9(1), pp. 23-45, 2004.

[51] Farooki, I., Denser living. Urban Environment Today, October 11, pp. 12-13, 2001.

[52] Cooper, J., Ryley, T. \& Smyth, A., The interaction between consumer response and urban design: empirical results from Belfast. Environment and Planning A, 33(3), pp. 1265-1278, 2001.

[53] Mulholland Research and Consulting, Perceptions of Privacy \& Density in Housing, Design for Homes Popular Housing Research: London, 2003.

[54] Barker, E., Review of Housing Supply - Delivering Stability: Securing Our Future Needs, Final Report-Recommendations, ODPM: London, 2004.

[55] Champion, A., Migration between Metropolitan and Non-Metropolitan Areas in Britain, University of Newcastle upon Tyne, Department of Geography: Newcastle upon Tyne, 1996.

[56] Champion, A., Atkins, D., Coombes, M. \& Fotheringham, S., Urban Exodus: A Report for the CPRE, University of Newcastle upon Tyne, Department of Geography: Newcastle upon Tyne, 1998. 
[57] David Cumberland Housing Regeneration Ltd., North East Housing Strategy, Government Office for the North East: Newcastle upon Tyne, 2003.

[58] Townshend, T.G., From inner city to inner suburb. Housing Studies, 21(4), pp. 501-521, 2006.

[59] Ball, M., Markets and the structure of the housebuilding industry: an international perspective. Urban Studies, 40(5), pp. 897-916, 2003.

[60] CPRE, Local Attraction: The Design of New Housing in the Countryside, CPRE: London, 1995.

[61] English Partnerships, Time for Design2, Good Practice in Building, Landscape and Urban Design, English Partnerships: London, 1998.

[62] Carmona, M., Housing Design Quality, through Policy, Guidance and Review, Spon Press: London.

[63] Barton, H. (ed.), Sustainable Communities, the Potential for Eco-Neighbourhoods, Earthscan: London, 2003.

[64] Association of Chief Police Officers Crime Prevention Initiatives Ltd., Secured by Design New Homes, ACPO-CPI Ltd: London, 2004.

[65] BRE, Eco-Homes - The Environmental Rating for Homes, Building Research Establishment: Watford, 2003.

[66] Guest, P., Fresh BREEAM. Building, 25(39), pp. 58-59, 1991.

[67] Rao, S., Yates, A., Brownhill, D. \& Howard, N., EcoHomes: The Environmental Rating for Homes, Building Research Establishment: Watford, 2000.

[68] Priaulx, M, Building for a future. EcoHomes, Spring, pp. 11-19, 2004.

[69] BRE Trust \& Cyril Sweett, Putting a Price on Sustainability, BRE: Watford, 2005. 